\title{
Analisis Pemikiran Umar bin Khațțab Tentang Pengguguran Hak Mu'allaf sebagai Mustahiq Zakat
}

\author{
Muhammad Syaifudin \\ Universitas Islam Negeri (UIN) Sunan Kalijaga Yogyakarta \\ Sayyy f@yahoo.com
}

\begin{abstract}
:
In the reign of Khulafaurrasyidin, the fourth caliph no longer provide the right of mu'allaf to the beneficiary, relying on Umar who flatly refuse to give alms to the rights of mu' allaf in the reign of Abu Bakr, and his reign. In fact, since the time of the Prophet they continue to receive zakat. This is where Omar issued a statement of law, that the al-mu'allafah qulübuhum not get the zakat, which none of the companions who opposed it. So opinions of Umar is a statute (ijmā') of the Companions and considered abrogated part mu'allaf. This paper studies about The reason of Umar bin Khattab did not provide the right of zakat to the mu'allaf as mustahiq of zakat, and how contemporary scholars put Umar thoughts about abortion right of mu'allaf as mustahiq of zakat in fiqh science literatures. The results of this research are, First, Umar bin Khațtab abort aṣnāf rights for "al-mu'allafah qulūbuhum" as a recipient of Zakat is due to the existence of a "illat (the reasons behind the solutions and decisions) that the state of "weak faith". Second, the science of fiqh repertory, contemporary scholars put the Umar thoughts as a basis of ijtihad with the provision if the spirit of the background ('illat law) is still visible, then the provisions of law applicable.
\end{abstract}

Keywords: Umar ibn al Khațab, ijtihad, Mu'allaf.

\begin{abstract}
Abstrak:
Pada masa Khulafaurrasyidin, keempat khalifah tidak lagi memberikan bagian mu'allaf kepada yang berhak, berpijak pada Umar bin Khațab yang dengan tegas menolak memberikan bagian zakat kepada para mu'allaf di masa pemerintahan Abu Bakar, dan di masa pemerintahannya. Padahal sejak masa Nabi mereka terus menerus menerima zakat. Di sinilah Umar mengeluarkan satu statemen hukum, bahwa al-mu'allafah qulübuhum tidak mendapatkan
\end{abstract}


bagian zakat, yang tidak ada satu pun dari sahabat yang menentangnya. Sehingga pendapat Umar bin Khatțab tersebut menjadi ketetapan (ijma') para sahabat dan dianggap menasakh bagian mu'allaf. Artikel ini membahas tentang alasan Umar bin Khattab tidak memberikan bagian zakat kepada mu'allaf sebagai mustahiq zakat dan Bagaimana ulama kontemporer mendudukkan pemikiran Umar bin Khatțab tentang pengguguran hak mu'allaf sebagai mustahiq zakat dalam khazanah ilmu fiqh. Hasil dari penelitian ini adalah, pertama, Umar bin Khatțab menggugurkan hak bagi așnāf "al-mu'allafah qulūbuhum" sebagai penerima zakat adalah karena adanya suatu 'illat (alasan-alasan dibalik solusi-solusi dan keputusan tersebut) yaitu keadaan "lemah agama". Kedua, dalam khazanah ilmu fiqh, ulama kontemporer meletakkan pemikiran Umar tersebut sebagai dasar ijtihad dengan ketentuan jika jiwa yang melatar belakangi ('illat hukum) itu masih terlihat, maka ketentuan hukum berlaku.

Kata Kunci: Umar ibn al Khațab, ijtihad, Mu'allaf.

\section{Pendahuluan}

Menurut syariat Islam, mustahiq zakat berjumlah delapan (al-aṣnāf al-thamāniyah), dan salah satunya adalah kelompok mu'allaf. Pada masa kenabian, zakat difungsikan sebagai media dakwah untuk menarik simpati orang-orang kafir terhadap Islam, demikianlah pemberian zakat kepada orang-orang mu'allaf tetap berlanjut hingga Rasulullah wafat.

Dan pada masa Khulafaurrasyidin, keempat khalifah tidak lagi memberikan bagian mu'allaf kepada yang berhak, berpijak pada Umar bin Khațtab yang dengan tegas menolak memberikan bagian zakat kepada para mu'allaf di masa pemerintahan Abu Bakar, dan di masa pemerintahannya. Padahal sejak masa Nabi mereka terus menerus menerima zakat. Di sinilah Umar mengeluarkan satu statemen hukum, bahwa al-mu'allafah qulübuhum tidak mendapatkan bagian zakat, yang tidak ada satu pun dari sahabat yang menentangnya. Sehingga pendapat Umar bin Khațab tersebut menjadi ketetapan (ijma') para sahabat dan dianggap menasakh bagian mu'allaf.

Berpijak dari uraian tersebut, ada dua permasalahan yang dirumuskan, pertama, alasan Umar bin Khatțab tidak memberikan bagian zakat kepada mu'allaf sebagai mustahiq zakat. Kedua, bagaimana ulama Khalaf (kontemporer) mendudukkan pemikiran Umar bin Khațab tentang 
pengguguran hak mu'allaf sebagai mustahiq zakat dalam khazanah ilmu fiqh.

Dalam penulisan ini menggunakan metode analisis deskriptif, yaitu dengan memaparkan kembali data yang sudah ada sebelumnya. Selanjutnya menganalisa data tersebut secara logis dan sistematis untuk menguji tingkat akurasi data yang sudah ada. Di samping juga menggunakan metode Ushuliyah guna memahami hakikat pemikiran Khalifah Umar bin Khațab dalam hal pengguguran hak mu'allaf sebagai mustahiq zakat. Karena Umar hidup pada beberapa abad lalu, maka digunakan pendekatan sejarah untuk merekontruksi apa yang terjadi pada masa dahulu agar bisa dicerna pada saat ini.

\section{Sekilas Biografi Umar bin Khaṭṭab}

Beliau adalah Umar bin Khattab bin Nufail bin Abdul Uzza bin Riyah bin Abdullah bin Qurth bin Razah bin Adi bin Ka'ab bin Lu'ai, Abu Hafs al'Adawi. Julukan beliau adalah Al-Fārūq. Ada yang menyebutkan bahwa gelar itu berasal dari Ahli Kitab (Ibnu Kathir, tt., 168). Sebelum Islam, suku Bani Adi ini terkenal sebagai suku yang terpandang mulia, megah dan berkedudukan tinggi (Syalabi, 1998: 236). Adi ini adalah saudara Murrah, kakek Nabi yang kedelapan. Ibunya Hantamah binti Hasyim bin al-Mughirah bin Abdullah bin Umar bin Makhzum (Haekal, 2011: 7).

Umar lahir pada tahun ketiga belas setelah peristiwa Tahun Gajah. Dia termasuk orang yang paling mulia di kalangan suku Quraisy. Masalahmasalah yang menyangkut diplomasi pada zaman Jahiliyah diserahkan kepada Umar. Jika di antara kabilah terjadi peperangan, maka Umar akan diutus sebagai penengah (Al-Suyuthi, 2010: 121).

Pada masa kanak-kanak ia menggembalakan gembala bapaknya di padang rumput sekitar Makkah. Sejak kecil ia belajar membaca dan menulis, pada saat itu orang yang telah bisa membaca dan menulis tidak lebih dari 17 orang di kalangan orang Quraisy. Setelah menginjak dewasa, Umar mulai senang membahas suatu masalah. Pada awal masa mudanya ia berdagang menjelajahi penjuru jazirah Arab. Umar pandai memanfaatkan kesempatan. Ia pergi ke Irak dan Syam bukan semata-mata untuk berdagang, akan tetapi juga untuk berkenalan dengan tokoh-tokoh kabilah negeri-negeri itu. Bagi 
kabilahnya Umar adalah seorang kurir yang istimewa dalam menghubungkan Quraisy dengan kabilah-kabilah lain. Ia seorang yang vokal berbicara, fasih lidahnya dan pandai menjelaskan sesuatu. Ia juga menghayati syair, menghafalnya bahkan juga membacakannya kepada orang lain (Haekal, 2011: 10-12).

Tentang wataknya yang kasar dan selalu bermuka masam serta hidupnya yang serba keras, merupakan sebagian dari wataknya yang sejak masa mudanya, dan kemudian tetap begitu dalam perjalanan hidup selanjutnya. Sesudah menjadi khalifah, maka dalam doa pertamanya ia berkata: "Ya Allah, aku sungguh tegar, maka lunakkanlah hatiku. Ya Allah, aku ini lemah, berilah aku kekuatan. Ya Allah aku sungguh kikir jadikanlah aku orang pemurah." Sejak mudanya ia sudah mewarisi sikap keras dan kasar itu dari ayahnya. Kemudian didukung pula oleh tubuhnya yang tetap kekar dan kuat (Haekal, 2011: 13).

Umar bin Khațab walaupun mempunyai watak yang keras, namun dengan kekerasannya itu tidaklah berarti ia seorang yang tamak dan rakus. Ia juga orang yang tak mau sewenang-wenang dengan kekuasaan yang dimilikinya. Ia adalah seorang yang kuat jiwanya. Ia adalah seorang yang adil, pandai dan penyayang terhadap sesama. Sifat-sifat ini merupakan satu kesatuan dalam dirinya. Ia adalah seorang pribadi yang besar. Umar memiliki watak keprajuritan, ia seorang pemberani, tangkas, patuh kepada peraturan dan tekun dalam tanggung jawab (Al-Aqqad, tt.: 60).

Sifat keras ini menjadi ciri khas Umar pada masa jahiliyah dan juga menjadi bagian kisah indahnya dalam Islam. Sebab beliau menggunakan sifat ini dalam melayani agama dan menegakkan perintah Allah SWT (AlHarithi, 2006: 19).

Dalam hubungannya dengan Nabi Muhammad, sebelum masuk Islam Umar adalah seorang pemuda dan pemuka yang sangat membenci Nabi Muhammad dan orang-orang yang menjadi pengikutnya. Kembali dengan terus terang di hadapan sahabat-sahabatnya. Katanya: "Apakah anda ingin mengetahui tentang awal keislamanku? sangat keras. Aku dulunya adalah salah seorang yang memusuhi Rasulullah SAW. Dengan mengutip riwayat dari Ibn Hisyam, Husain Haekal menulis, bahwa pada sutu hari Abu Bakar melihat Umar menyiksa dan memukul seorang budak perempuan supaya 
meninggalkan Islam. Demikian rupa ia menghajar hingga ia merasa bosan sendiri karena sudah terlalu banyak ia memukul. Saat itulah kemudian budak itu ditinggalkan oleh Umar sambil berkata: Aku memaafkan kau! Kutinggalkan kau hanya karena sudah bosan. Hamba sahaya itu menjawab: Itulah yang dilakukan Allah kepadamu. Kemudian hamba sahaya itu dibeli oleh Abu Bakar lalu dibebaskan (Haekal, 2011: 17).

Umar masuk Islam pada tahun keenam kenabian. Saat itu ia berusia 27 tahun, tatkala itu jumlah sahabat yang memeluk Islam berjumlah sekitar empat puluh orang laki-laki dan sebelas wanita. Atau, sebagaimana disebutkan dalam riwayat lain, yaitu tiga puluh orang laki-laki dan dua puluh tiga wanita. Sebagaimana juga disebutkan dalam sebuah riwayat jumlahnya adalah empat puluh lima orang laki-laki dan sebelas perempuan. Tatkala dia menyatakan keislamannya, Islam semakin kokoh di kota Makkah dan kaum muslimin bersuka cita dengan keislamannya (As-Suyuthi, 2010: 121).

Umar masuk ke dalam agama Allah ini dengan semangat yang sama dengan seperti ketika dulu memusuhi Islam. Begitu ia berada dalam keluarga Islam, ia lebih cenderung mengumumkan keislamannya itu terang-terangan kepada semua orang Quraisy. Sebelum itu kaum muslimin tak dapat melaksanakan shalat di Ka'bah, tetapi dengan kegigihan Umar melawan kaum Quraisy merekapun dibiarkan shalat di sana. Dakwah Islam yang mulanya dilakukan dengan sembunyi-sembunyi, setelah Umar masuk Islam dakwah dilakukan secara terang-terangan. Kaum Muslimin kini sudah dapat duduk di sekitar ka'bah dan melakukan tawaf serta berlaku adil terhadap orang yang dulu memperlakukan mereka dengan kasar (Haekal, 2011: 35).

Ketika itu ia termasuk Muslim yang paling tabah dan sabar dalam menanggung penderitaan, dan yang paling keras memberikan pembelaan sedapat yang dapat dilakukannya dalam menghadapi gangguan kepada Rasulullah dan saudara-saudaranya kaum muslimin. Dia juga orang yang sangat meyakini ketertiban dan berusaha sedapat mungkin menaati dan menjaganya. Yang demikian ini sudah menjadi bawaannya sejak masa jahiliah, dan lebih-lebih lagi sesudah dalam Islam (Haekal, 2011, 37).

Umar bin Khatțab adalah salah satu sahabat Nabi yang dibuat berbeda oleh Islam dengan segala apa yang diberikan kepadanya. Sosok yang satu ini seperti tak pernah kering sebagai sumber inspirasi dan ilmu bagi banyak 
orang. Khalifah kedua dalam urutan Khulafa' Arrasyidin ini selalu saja menjadi objek kajian dan penelitian yang menarik minat para ulama, cendekiawan dan ilmuwan (Al-Harithi, 2006: VII).

Umar adalah sahabat Nabi yang setia, patuh dan berani. Watak keprajuritan yang dimiliki Umar telah mendorong dirinya untuk memiliki sifat suka patuh, karena kepatuhannya inilah Umar mau mengerjakan apa saja diperbuat Nabi, walaupun belum tentu sesuai dengan sikap kritisnya, seperti riwayat Imam Bukhari yang menceritakan tentang Umar ketika ia mencium hajar aswad selesai tawaf : bahwa dia mendatangi hajar aswad kemudian menciumnya dan berkata "aku mengetahui sesungguhnya kamu hanyalah sebuah batu, yang tidak memberikan bahaya dan tidak memberi manfaat, seandainya bukan karena aku melihat Rasulullah menciummu, aku tidak akan menciummu." (al-Bukhari, t.t: 579).

Kesetiaannya kepada Rasul ini selanjutnya melahirkan sikap selalu bersedia dan berani membela dan menyelamatkan Rasulnya dari segala marabahaya yang akan menimpa. Keberaniannya yang disegani orang, yang telah dimilikinya dan telah dikenal orang sejak sebelum ia masuk Islam, bukan saja telah secara langsung memperkuat Islam tetapi juga telah menyebabkan orang mulai segan dengan Islam itu sendiri. Masuknya Umar kedalam Islam adalah faktor utama yang telah memperkuat posisi Nabi untuk melangkah dari fase berdakwah secara sembunyi-sembunyi dan terbatas terhadap kaum kerabat kepada fase terang-terangan yang terbuka terhadap segala orang dari segala penjuru dan lapisan masyarakat.

Sebelum Umar masuk Islam, kaum muslimin melakukan ibadah secara sembunyi-sembunyi, kadang-kadang sampai dibalik bukit-bukit, setelah Umar masuk Islam, dengan dikawal oleh Umar sendiri dan paman Nabi Hamzah pada suatu hari kaum muslimin berbaris melakukan ibadah dan tawaf secara terang-terangan disisi ka'bah, sementara di sekitar mereka adalah kaum musrik Quraisy yang sedang menyembah berhala yang juga terletak berjejer di sekelilingku Ka'bah. Pada waktu itulah Nabi memberi gelar " AlFārūq" kepada Umar bin Khațtab karena keberaniannya" (Al-Aqqad, t.t: 48).

Demikian pula ketika perintah berhijrah datang, kaum muslimin yang lain berangkat dengan sembunyi-sembunyi, tetapi Umar sebaliknya. 
Disiapkannya busur panah di tangannya, dinaikinya kuda, kemudian berangkat dengan melewati Ka'bah dan singgah pula di situ. Orang-orang kafir Quraisy sedang banyak berkerumun di tempat itu. Umar melakukan tawaf tujuh kali, shalat sunnat tujuh kali, shalat sunnat di maqam Ibrahim, setelah itu ia berseru kepada kaum Quraisy yang hadir, katanya dengan suara lantang dan keras, "Siapa yang ingin ibunya menangis atau anaknya menjadi yatim atau istrinya menjadi janda, majulah berhadapan denganku di balik lembah ini (Al-Aqqad, t.t: 84-85).

Umar juga seorang sahabat Nabi yang kuat ilmu dan agamanya. Kepandaian Umar telah dirintisnya sejak ia masih kanak-kanak ketika belajar mambaca dan menulis, yang kemudian ditopang dengan kegemarannya untuk membahas beragam masalah ketika ia beranjak dewasa. Berbagai masalah yang ditugaskan kepadanya diselesaikannya dengan gemilang. Ketika Nabi wafat, karena kejauhan pandangannya mengatakan bahwa hal itu akan menggoncangkan keadaan kaum muslimin. Mengenai tawanan perang Badar, ketinggian daya analisanya mengatakan bahwa semangat perlawanan dalam hati para tawanan itu tetap berkobar, karenanya, sebaiknya mereka dibunuh saja. Bahkan pikiran-pikirannya itu sering mendapat persetujuan dari wahyu seperti pendapatnya tentang masalah memerangi orang-orang munafik, pengharaman khamar, masalah hijab bagi isteri-isteri Nabi, dan lain-lain (ashShiddieqy, 1971, 73) Demikian tinggi kecerdasan Umar sampai Nabi pernah bersabda bahwa Allah meletakkan kebenaran di lidah dan hati Umar (AlTirmidhi, t.t: 617).

Ketika Abu Bakar al-Ṣiddiq wafat pada hari Senin, setelah Maghrib dan dikuburkan pada malam itu juga, bertepatan pada tanggal 21 Jumadil Akhir tahun $13 \mathrm{H}$, Umar bin al-Khaththab Al-Fārūq menggantikan seluruh tugas-tugasnya dengan sebaik-baiknya sebagai Amirul Mukminin. Beliaulah yang pertama kali menyebut dirinya dengan gelar Amirul Mukminin -orang yang pertama kali memanggilnya dengan gelar tersebut adalah al-Mughirah bin Syu'bah- dan ada yang berpendapat bukan al-Mughirah tetapi orang lain (Ibnu Kathir, t.t: 191).

Umar bin Khațab melaksanakan tugas dalam kekhalifahan selama 10 tahun dan 6 bulan, kurang lebih, dan mampu merealisasikan hal-hal yang besar dalam tersebut, yang tidak mungkin disebutkan seluruhnya dalam 
ruang yang singkat ini membicarakan seluruh keberhasilan Umar selama masa kepemimimpinannya membutuhkan kajian tersendiri (Al-Harithi, 2006: 25).

Kepemimpinan Umar selama menjabat sebagai Khalifah telah dicatat dalam sejarah sebagai kepemimpinan yang sangat dibanggakan, baik di bidang politik teritorial, sosio-ekonomi maupun sosio-kultural. Menurut yang diriwayatkan oleh Ibnu Athir bahwa Abdullah Ibnu Mas'ud berkata: "Islamnya Umar adalah kemenangan, hijrahnya adalah pertolongan dan kekhalifahan serta pemerintahannya adalah rahmat (Syalabi, 1998: 236).

\section{Metode Ijtihad Umar bin Khațțab}

Untuk mengetahui Konsep Umar bin Khațtab dalam menetapkan suatu hukum terhadap suatu masalah dapat kita amati dari pesan-pesan Umar bin Khattab kepada para Hakim yang diangkat dan ditugaskannya di berbagai daerah.

Ada dua surat penting yang secara historis dinisbatkan kepada Umar bin Khattab dan berisi tentang mekanisme penetapan hukum. Yang pertama pendek dan hanya memuat sedikit masalah-masalah yang berkenaan dengan hukum. Surat ini dikirim oleh Umar kepada Syuraih yang menjabat sebagai Qadhi (hakim) di Kufah. Surat kedua cukup panjang dan sangat detil. Menurut sebuah sumber, surat kedua ini dikirim Umar kepada Abu Musa Al-Asy'ari yang menjabat sebagai Qadhi di Bashrah (Baltaji, 2005: 37).

Jika kita menerima validitas penisbatan kedua surat ini kepada Umar, maka kita bisa menganggap keduanya sebagai media awal untuk mengenal lebih jauh manhaj Umar dalam masalah penetapan hukum, utamanya surat Umar yang panjang yang dikirim kepada Abu Musa Al-Asy'ari. Hal ini dikarenakan kedua surat tersebut memuat beberapa dasar (kaidah) penting dalam masalah penetapan hukum yang dianut oleh Umar dan direkomendasikan untuk dilaksanakan oleh para Qadhi yang diangkatnya.

Ibnul Qayyim meriwayatkan, bahwa Umar bin Khatțab menulis surat kepada Qadhi Syuraih yang isinya;

"Jika kamu menghadapi suatu masalah penting, maka lihatlah dulu Kitabullah, kemudian putuskanlah hukum itu dengan (berpedoman 
kepada isi)nya. Jika kamu tidak menemukan dalam Kitabullah, maka lihatlah dalam kasus-kasus yang pernah diputuskan oleh Rasulullah. Jika kamu juga tidak menemukannya, maka lihatlah dalam kasuskasus yang pernah diputuskan oleh para orang saleh dan juga para pemimpin yang adil. Dan jika kamu tidak mendapatkannya juga, maka kamu boleh memilih; jika kamu ingin melakukan ijtihad dengan nalarmu maka lakukanlah, dan jika kamu ingin mengkonsultasikannya denganku (maka lakukanlah) dan saya menilai bahwa pilihanmu untuk berkonsultasi denganku itu adalah langkah yang akan memberikanmu kebaikan (Ibnul Qayyim, t.t: 49).

Ibnul Qayyim juga meriwayatkan, bahwa Umar menulis Surat untuk Abu Musa Al-Asy'ari yang isinya;

“Ammā ba'du. Sesungguhnya menetapkan hukuman (al-qad̄ā) adalah satu kewajiban yang pasti dan termasuk tradisi yang otentik. Jika ada satu permasalahan datang kepadamu, maka ketahuilah bahwa ucapan yang benar tidak akan ada manfaatnya bila tidak diikuti dengan implementasi riil.

Ketika ada orang (dengan berbagai latar belakang strata sosial) berada di majelis pengadilan, perlakukanlah mereka dengan sama, pandanglah mereka dengan pandangan yang sama. Hendaknya hukuman yang kamu putuskan juga sama (tidak ada diskriminasi), sehingga orang yang mulia (yang mempunyai status sosial yang tinggi) tidak akan mengharap kamu melakukan kezaliman dan supaya orangorang yang lemah tidak kehilangan harapan untuk mendapatkan keadilan kamu.

Barang bukti adalah kewajiban yang harus diberikan oleh orang yang menuduh, dan sumpah adalah penguat bagi pihak yang menolak tuduhan tersebut. Kesepakatan untuk berdamai yang dilakukan oleh sesama umat Islam dibolehkan, kecuali jika kesepakatan damai tersebut menyebabkan hal-hal yang diharamkan menjadi halal atau hal-hal yang halal menjadi haram.

Barangsiapa mengklaim ada hak yang terabaikan, maka berilah dia tenggang waktu, jika dia sanggup menerangkan duduk perkara tersebut (dengan bukti-bukti kuat), maka berikanlah hak tersebut kepadanya. Namun jika dia gagal meyakinkanmu, maka masalahnya terpecahkan dengan sendirinya. Ini adalah cara yang tepat (untuk menyelesaikan sengketa).

Jika kamu mendapatkan petunjuk (keyakinan) baru yang bisa mengubah keputusan yang telah kamu tetapkan hari ini, maka jangan 
takut (malu) untuk mengubah keputusan baru yang benar, karena sesungguhnya kebenaran tidak bisa dikalahkan oleh apapun. Dan mengoreksi diri untuk mendapatkan kebenaran, lebih baik daripada terus-terusan berada dalam kebatilan.

Semua orang muslim adalah adil (terpercaya), kecuali orang yang sudah pernah melakukan sumpah palsu atau dicambuk karena putusan hukum (hudūd) atau diragukan loyalitas dan kedekatannya (dengan Islam). Yang mengetahui rahasia-rahasia manusia hanyalah Allah. Allah akan tetap menutupi putusan-putusan hukum hingga ada bukti-bukti atau sumpah (yang akan memperjelas duduk perkara yang terjadi).

Jika kamu menghadapi masalah yang hukumnya tidak disinggung secara eksplisit dalam Al-Qur'an atau sunnah, maka gunakanlah akal yang dianugerahkan kepadamu dengan cara mengqiyaskan masalahmasalah tersebut. Ketahuilah dengan baik contoh-contoh kasus (yang hukumnya disebutkan secara eksplisit dalam Al-Qur'an) kemudian ambillah keputusan yang sekiranya kamu yakin bahwa keputusan tersebut adalah keputusan yang lebih dicintai Allah dan lebih dekat dengan kebenaran.

Jauhilah sikap marah, bingung, menyakiti orang lain, dan mempersulit permasalahan ketika terjadi sengketa. Putusan hukum yang tepat, mengenai sasaran kebenaran, akan mendapatkan pahala dari Allah, dan akan selalu dikenang. Barangsiapa dalam melakukan kebenaran didasari dengan niat yang ikhlas, maka dia akan merasa cukup hanya Allah-lah (yang akan melindungi dan menolongnya dalam masalahmasalah) yang menyangkut dirinya dan orang lain.

Barangsiapa mangada-ada maka Allah akan mencelanya. Sesungguhnya Allah tidak akan menerima amal seorang hamba kecuali amal yang didasari dengan keikhlasan.

Bagaimanakah pendapatmu mengenai pahala-pahala Allah baik berupa rezeki yang kamu dapat di dunia dan rahmat-rahmat-Nya yang masih tersembunyi. Wassalam" (Ibnul Qayyim, t.t: 67).

Dalam menerapkan hukum Islam, Umar sangat mempedulikan nasnas keagamaan dan bahkan tidak mungkin melanggarnya. Bahkan dia berusaha untuk memakainya dan Umar sangat disiplin dalam mengimplementasikan teks-teks keagamaan. Di samping itu ia juga disiplin dalam merealisasikan kemaslahatan umum dalam posisinya sebagai khalifah yang dipilih oleh rakyat. Dengan kata lain, umar selalu disiplin dalam mengapli- 
kasikan syariat dan dalam waktu yang bersamaan menjamin terealisasinya kemaslahatan umum.

Pendekatan Umar yang sejak dari awal terlihat lebih banyak bersifat rasional dan intelektual, telah membawanya untuk melahirkan perubahanperubahan hukum secara formal terutama dalam menghadapi wahyu Allah dan Sunnah Rasul-Nya. Perubahan-perubahan hukum itu untuk sebagian besar dipengaruhi oleh kondisi dan situasi, di mana tuntunan kemaslahatan dan kepentingan umum yang merupakan tujuan akhir dari syariah menghendaki yang demikian (Abu Zahrah, t.t: 20).

Perubahan hukum secara formal, nampaknya dilakukan oleh Umar karena adanya pemahaman yang total terhadap pesan-pesan al-Qur'an dan Sunnah Rasul. Dan betapapun perubahan itu telah terjadi, bukanlah berarti ia meninggalkan, apalagi membatalkan nash-nash al-Qur'an. Adalah merupakan suatu kekeliruan, bagi orang yang memahami kebijakan Umar sebagai tindakan yang meninggalkan sebagian nash-nash al-Qur'an, demi kemaslahatan dan pertimbangan pribadi. Akan tetapi yang sebenarnya Umar telah menerapkannya dengan baik dan memahami secara kreatif dan sehat, tanpa ragu-ragu terhadap tujuan-tujuan syariah (Abu Zahrah, t.t: 20).

Yang perlu diperhatikan disini adalah karakter penetapan hukum dalam Islam pada waktu itu adalah dilakukan secara gradual sesuai dengan perkembangan kondisi yang ada dan tidak memberi hak menetapkan hukum kepada salah seorang sahabat pun sampai dasar-dasar sistem Islam yang dikehendaki oleh Allah terkonfigurasi dengan sempurna (Baltaji, 2005: 34). Sebelum Rasulullah wafat, wahyu telah menyelesaikan tugasnya yaitu meletakkan dasar-dasar hukum Islam dan juga kaidah-kaidah umum keberagamaan.

Perbedaan krusial antara ijtihad yang dilakukan oleh kaum muslimin pada masa kerasulan dengan ijtihad yang mereka lakukan setelah Rasulullah meninggal, adalah bahwa hak otoritatif dalam menetapkan hukum pada masa kerasulan hanya diwakili oleh wahyu, pada masa itu Rasulullah adalah satusatunya interpretator dan legistator ketetapan-ketetapan hukum Al-Qur'an. Dan wahyu selalu mengawasi dan mengoreksi pelaksanaan aturan-aturan hukum tersebut. 
Adapun setelah syariat sempurna dengan ditandai sempurnanya peletakan nilai-nilai dasar universal dan juga meninggalnya Rasul, maka pengimplementasian nilai-nilai universal ini dipasrahkan sepenuhnya kepada ijtihad para cendekiawan dari setiap generasi yang berada pada lingkunganlingkungan yang beragam (Baltaji, 2005: 35).

Rentang waktu yang melingkupi manhaj Umar bin Khațab dalam masalah ijtihad dan penerapan hukum dimulai sejak wafatnya Rasulullah pada bulan Rabiul Awwal $11 \mathrm{H}$ dan selesai hingga Umar meninggal dunia pada bulan Dzulhijjah 23 H (632-643 M). Dengan kata lain, selama dua belas tahun, sembilan bulan dan beberapa hari, sesuai dengan hitungan tahun Hijriyah yang ditetapkan oleh Umar bin Khațtab (Baltaji, 2005: 37).

\section{Pemikiran Umar tentang Pengguguran Hak Mu'allaf sebagai Mustahiq Zakat}

Al-Fārūq Umar sangat yakin bahwa Islam adalah jiwa dan akidah. Orang tidak akan sempurna imannya sebelum ia memahami jiwa agama yang sebenarnya diwahyukan Allah kepada Rasul-Nya. Oleh karena itu ketentuanketentuan hukum Qur'an yang diturunkan disesuaiakan dengan jiwa yang menyertainya. Jika di dalamnya terdapat sunnah yang berasal dari Rasulullah dalam kata atau perbuatan, pertalian sunnah itu perlu diketahui untuk kemudian diterapkan dengan sangat hati-hati (Haekal, 2011: 690).

Di dalam Al-Quran, Allah telah menjelaskan bahwa kelompokkelompok atau golongan-golongan yang berhak menerima zakat (mustahiq zakat) adalah berjumlah delapan atau yang biasa dikenal dengan istilah delapan așnāf, Allah berfirman dalam Al Qur'an surat al-Taubah ayat 60:

"Sesungguhnya zakat-zakat itu, hanyalah untuk orang-orang fakir, orang-orang miskin, pengurus-pengurus zakat, para mu'allaf yang dibujuk hatinya, untuk (memerdekakan) budak, orang-orang yang berhutang, untuk jalan Allah dan untuk mereka yang sedang dalam perjalanan, sebagai suatu ketetapan yang diwajibkan Allah, dan Allah Maha mengetahui lagi Maha Bijaksana.”

Secara umum, ayat tersebut tidak mengatur bagaimana seharusnya dan sebaiknya membagikan harta zakat kepada mustahiqnya yang delapan 
macam itu. Oleh karena itulah, ulama dengan mempergunakan argumentasi mereka masing-masing, berbeda pendapat. Di antara mereka ada yang mengharuskan pembagian secara merata kepada semua kelompok (aṣnāf yang delapan), ada pula yang tidak mengharuskannya. Penyebab terjadinya perbedaan pendapat itu, menurut Ibnu Rusyd, ialah adanya sebagian ulama yang terikat oleh tekstual ayat, yang menghendaki pembagian kepada semua kelompok. Sedangkan yang lain berpegang kepada makna esensial dari ayat yang tujuannya untuk menyelesaikan suatu problem sosial dalam masyarakat Islam (Ibnu Rusyd, t.t: 612).

Salah satu dari delapan golongan yang telah ditetapkan oleh Allah sebagai penerima zakat adalah kelompok mu'allaf. Rasulullah saw semasa hidupnya selalu memberikan zakat kepada delapan aṣnāf tersebut secara lengkap, termasuk memberikan zakat kepada așnāf "al-Mu'allafah Qulubuhum". Beberapa orang yang oleh Nabi diberi zakat atas kriteria tersebut di antaranya adalah Abu Sufyan dan Uyainah bin Hasan. Șafwan bin Umayyah berkata, "Demi Allah, Rasulullah telah memberiku (bagian zakat) padahal beliau adalah orang yang paling aku benci. Dan beliau terus memberiku (bagian zakat) sehingga beliau termasuk orang yang paling aku cintai” (Muslim, t.t: 1806).

Pemberian itu diberikan sebagai pelunak hati mereka, agar tidak terpikir oleh mereka untuk memusuhi Islam yang telah mengalahkan mereka, dan untuk menarik simpati mereka agar mengikuti dakwah baru ini (Islam). Jika hati mereka telah lunak, maka keinginan untuk dendam dan semisalnya, dengan sendirinya akan hilang.

Adanya pembagian jatah atau pemberian harta seperti itu, di samping menguntungkan mereka (orang-orang non muslim), juga bermanfaat bagi Islam. Kebanyakan mereka adalah para pembesar dan pemimpin kaum. Sedangkan kebanyakan pengikut agama baru ini adalah rakyat jelata dan hamba sahaya yang merindukan kebebasan, kemerdekaan dan persamaan di bawah lindungan agama yang menyuarakan hal tersebut.

Oleh karena itu tidak mengherankan lagi jika kebanyakan orangorang yang mau ditundukkan hatinya (al-Mu'allafah Qulubuhum) adalah para pembesar dan orang-orang yang terhormat kaum, yang mereka itu terdiri dari tiga macam kelompok (Baltaji, 2005: 179): 
1. Orang-orang musyrikin yang hatinya masih jauh dan asing dari keislaman. Mereka diberi bagian dari harta Islam dengan maksud agar mereka tidak menyakiti dan mengganggu orang muslim, dan juga agar bisa dimintai tolong bila ada kelompok-kelompok lain dari golongan mereka orang kafir, jika pertolongan itu memang dibutuhkan. Hal ini juga dimaksudkan agar mereka tidak bersama-sama dan bersatu padu menyerang Islam yang baru tumbuh itu.

2. Orang-orang musyrikin dari kalangan para pembesar dan orang-orang terhormat. Mereka ini orang-orang yang bisa menimbulkan kembali permusuhan kepada Islam. Oleh karena itu Rasulullah memberikan mereka bagian zakat dan berusaha mendekati mereka agar mereka mau bergumul dengan dakwah Islamiyah. Jika demikian, maka bisa saja mereka itu akan beriman atau minimal frekuensi mereka dalam memusuhi Islam akan berkurang. Dan mereka pun tidak akan mengintimidasi atau menghalang-halangi kaumnya yang hendak memeluk Islam.

3. Orang-orang yang baru masuk Islam dan imannya masih lemah, mudah goyah, dalam benaknya masih tersimpan sisa-sisa materialisme yang dulu menjadi pujaan dalam hidupnya. Maka mereka diberi bagian zakat agar mereka tidak kembali kepada kekafiran, jika terdesak kebutuhan ekonomi. Hal ini dilakukan karena Rasul tahu bahwa orang lapar yang lemah akidahnya, tentu akan sulit baginya mengimani apa saja.

Rasulullah tidak pernah menahan atau menyisakan harta maupun tenaganya jika untuk kepentingan kebaikan di jalan Allah. Diriwayatkan dari Anas bin Malik, bahwa Rasulullah tidak pernah dimintai sesuatu apapun, kecuali beliau memberikannya.

Dari Anas bahwasanya Rasulullah tidak pernah dimintai sesuatu apapun kepadanya atas nama Islam, melainkan beliau memberikannya. Pernah datang Seorang laki-laki kepadanya, dan serta merta meminta harta kepada beliau, maka Nabipun menyuruh memberikan kepadanya sekumpulan kambing hasil zakat yang memenuhi lembah antara dua bukit. Kemudian orang itu kembali kepada kaumnya lalu berkata: wahai kaumku, masuk Islamlah kalian semua, Karena sesungguhnya Muhammad memberikan sesuatu pemberian yang sangat banyak, tanpa sedikit pun kuatir jatuh melarat" (Al-Shaukani, tt.,178). 
Rasulullah memberikan bagian zakat kepada mereka itu dan juga yang lainnya, dan tidak memberikan bagian ini kepada banyak kaum muslimin yang benar-benar kuat dan tulus keislamannya, meskipun jerih payah dan kesibukan mereka berjihad dan berdakwah tentunya sangat layak untuk menerima bagian tersebut. Hal ini menyebabkan salah seorang sahabat pernah bertanya kepada beliau, "Wahai Rasulullah, engkau memberikan bagian kepada Uyainah bin Hisham dan Aqra' bin Hāābis, tapi mengapa Juail bin Suraqah Al-Damari tidak engkau berikan? Rasulpun menjawab, "Demi Tuhan yang jiwa Muhammad berada di dalam genggaman-Nya, Ju'ail bin Suraqah adalah lebih baik dan lebih utama daripada seluruh apa yang ada di muka bumi ini, seperti 'Uyainah bin Hishn dan juga Aqra' bin Hāäbis. Namun hal itu (aku lakukan) untuk menarik hati keduanya untuk masuk Islam. Dan aku serahkan Juail bin Suraqah pada keislamannya (tidak perlu diberi karena telah kuat imannya)" (Al-Ṭabāri, t.t: 332).

Nabi s.a.w. memanggil 'Uyainah bin Hiṣn dengan "al-Aḥmaq al-Muṭat' fi Qaumihi (orang bodoh yang ditaati kaumnya)”, karenanya ia perlu dibujuk rayu hatinya. Sedangkan Ju'ail adalah orang yang sangat fakir dari golongan ahli Shuffah (Baltaji, 2005: 198).

Demikianlah, pemberian bagian zakat kepada orang-orang Mu'allaf tetap berlanjut hingga Rasulullah meninggal. Pada masa kekhalifahan Abu Bakar, ketika kaum muslimin berhasil menumpas orang-orang murtad dan para pembangkang yang tidak mau membayar zakat, maka ajaran Islam menyebar di seluruh jazirah Arab. Kekuatan Islam semakin kuat, bahkan tidak hanya di jazirah Arab saja, akan tetapi juga di luar Arab. Kekuatan Islam bisa mengimbangi dua super power saat itu, yaitu Romawi dan Persia. Kekuatan kedua imperium ini semakin menyusut dan lumpuh ketika mereka membiarkan kekuatan Islam ini menghancurkan dan mengikis kekuatan mereka, sebagaimana yang terjadi pada kekhalifahan Umar bin Khatțab.

Di akhir masa kekhalifahan Abu Bakar, setelah ia berhasil menaklukkan kota Hauzan, datanglah dua orang mu'allaf menemui sang khalifah. Mereka berdua ini ingin meminta bagian zakat dari khalifah berupa tanah sebagaimana Nabi memberikan bagian kepada mereka (Baltaji, 2005: 181).

Diriwayatkan dari Abdurrahman bin Muhammad al-Muharibi, dari Ḥajjāj bin Dīnār dari Ibnu Sirīn dari 'Ubaidah ia berkata: bahwa suatu saat, 
'Uyainah bin Ḥiṣn dan al-Aqra' bin Ḥābis datang kepada Khalifah Abu Bakar untuk meminta bagian zakat mereka dari golongan mu'allaf berupa tanah sebagaiman yang telah diberikan oleh Nabi ketika beliau masih hidup. Keduanya berkata, "Sesungguhnya di tempat kami ada tanah-tanah kosong, yang tidak berumput dan tidak berfungsi, bagaimana jika tanah itu anda berikan kepada kami?" Maka Abu Bakar membuat surat (catatan) untuk mereka untuk diserahkan kepada Umar bin Khațab, ketika itu Umar tidak ada di situ, namun ketika mereka menyerahkan surat tersebut kepada Umar, ia menolak untuk memberikan zakat kepada mereka dan langsung menyobek surat itu kemudian berkata, "Dahulu Rasulullah menganggap kalian sebagai mu'allaf, ketika Islam saat itu masih kecil dan pemeluknya masih sedikit. Sedangkan sekarang Allah telah menjadikan Islam besar dan jaya, maka pergilah kalian bekerja sebagaimana kaum muslimin bekerja"(Ibn Kathir, t.t: 259). Selanjutnya Umar bin Khațtab mengutip al-Qur'an surat al-Kahfi ayat: 29 yang berbunyi (Al-Ṭabāri, t.t: 400):

"Dan katakanlah kebenaran itu datangnya dari Tuhanmu, Maka barang siapa yang ingin (beriman) hendaklah ia beriman, dan barangsiapa yang ingin (kafir) biarlah ia kafir”.

Mendengar kata-kata Umar bin Khațab seperti ini, mereka langsung datang kepada Abu Bakar dan berkata, "Siapakah yang sebenarnya menjadi khalifah, kamu atau Umar? Kami menyerahkan suratmu tetapi disobek oleh Umar". Maka Abu Bakar menjawab, "(Terserah) dia, jika ia mau (menyobeknya)" (Sābiq, 1992: 330).

Umar kemudian mengeluarkan satu statemen hukum, bahwa almu'allafah qulübuhum tidak mendapat bagian zakat, yang tidak ada satupun dari sahabat yang menentangnya. Mereka menyetujui pendapat dan apa yang dilakukan Umar tersebut.

\section{Alasan dan Latar Belakang Pemikiran Umar}

Dilihat dari klasifikasi golongan mu'allaf, sebagaimana dirinci oleh fuqaha, maka bagian zakat untuk aṣnāf al-mu'allafah qulūbuhum, itu karena ada tujuan-tujuan dan maksud-maksud tertentu yang sifatnya sangat 
kondisional. Oleh sebab itulah, di waktu kondisi umat Islam telah kuat dan stabilitas pemerintahan sudah semakin mantap, Umar menghentikan pemberian bagian mu'allaf, bukan saja kepada orang-orang yang sebelumnya pernah menerima bagian mu'allaf, tetapi juga kepada orang-orang lain yang semacamnya. Umar mencabut perintah yang dituliskan Abu Bakar di kala ia masih menjadi khalifah untuk memberikan tanah-tanah tertentu pada sejumlah orang atas dasar ini, Umar berpendapat bahwa Rasulullah telah memberikan bagian itu untuk memperkuat Islam, tetapi karena keadaan telah berubah maka bagian itu tidak berlaku lagi (Hasan, 1970: 107).

Umar mencegah pemberian bagian zakat kepada para mu'allaf di masa pemerintahan Abu Bakar, dan di masa pemerintahannya, karena pada masa pemerintahan Abu Bakar dan masa kekhalifahan sang khalifah kedua ini sudah tidak dijumpai lagi orang-orang yang layak disebut al-mu'allafatu qulübuhum (orang-orang yang ditaklukkan hatinya). Ini persis seperti manakala pada suatu masa, di suatu tempat tertentu tidak ditemukan adanya orang fakir dan miskin. Tentu kita tidak mengamalkan apa yang tersurat dalam Al-Qur'an tentang bagian mereka, sampai ditemukan kembali orangorang fakir dan miskin di tempat tersebut (Baltaji, 2005: 182).

Setelah Rasulullah s.a.w. wafat, dan Islam telah tersebar di seluruh semenanjung Arab, orang-orang Islam melewati ujian berat bertempur melawan kawan sendiri yang murtad, yang akhirnya dalam sekejap saja berakhir dengan tunggang-langgangnya orang-orang murtad tersebut dan menyerah tanpa syarat kepada pasukan Islam. Setelah itu semakin jelaslah dan nyata bahwa kekuatan Islam adalah luar biasa, suaranya membahana di seantero Arab, dan gaungnya menggema ke mana-mana, sampai jauh keluar jazirah Arab, memenuhi ufuq dan menembus cakrawala. Karenanya tidak diperlukan lagi penghambur-hamburan kas negara untuk menarik simpati dan membujuk orang untuk masuk Islam.

Inilah yang menjadi alsan mengapa Abu Bakar dan seluruh sahabat yang lain dengan secara spontan sepakat menerima pendapat Umar, tanpa harus didahului adu argumen terlebih dahulu. Mereka merasa diingatkan oleh Umar tentang hakikat Islam yang sekarang, yang sudah sangat kuat, tidak perlu lagi menghamburkan uang untuk menarik simpati orang lain non muslim. Sebagaimana yang dikatakan Umar, "Sesungguhnya Allah telah 
menjadikan Islam ini besar dan jaya. Kebenaran adalah dari Tuhan kalian. Maka barangsiapa yang mau beriman, maka berimanlah, dan barangsiapa yang tidak mau beriman, maka kafirlah”. Dan bagaimana mungkin, Islam masih harus membujuk-bujuk hati orang agar mau memeluknya, sedangkan pasukannya saja mampu menggetarkan dan memporak-porandakan kekuatan super power kala itu, yaitu imperium Persia dan Romawi.

Dengan demikian, tidak diragukan lagi bahwa hukum tentang ada dan tidaknya orang-orang mu'allaf, disesuaikan dengan situasi dan kondisi yang ada di tengah-tengah masyarakat muslim. Kalau memang dibutuhkan atau ada, maka ketika itulah hak-hak mereka diberikan, sebagaimana ketentuan dalam Al-Qur'an, tapi kalau tidak ada atau sudah tidak diperlukan, bagaimana mungkin harus dipaksakan? Oleh karena itu, jelaslah, bahwa Umar, Abu Bakar dan juga para sahabat yang lain tidak menyalahi teks-teks Al-Qur'an ataupun melanggar apa yang telah dilakukan Nabi. Karena apa yang mereka lakukan, tidak ada niatan sedikitpun untuk mengesampingkan ayat Al-Qur'an atau bahkan menghapusnya. Mereka hanya menahan bagian yang sudah tidak ada pemiliknya. Sehingga kalau seandainya pada masa Umar ataupun setelahnya ada kondisi-kondisi dan alasan yang memungkinkan dibagikannya bagian-bagian tersebut kepada yang berhak, tentu mereka akan mengeluarkannya dan memberikan kepada pemilikpemiliknya yang berhak (Baltaji, 2005: 183-184).

Menurut Ahmad Azhar Basyir (Basyir, 1988), sesungguhnya Umar telah melakukan istinbat dengan menentukan 'illat hukum yang tidak disebutkan di dalam naș, sehubungan dengan tidak lagi diperlukannya pemberian zakat kepada mu'allaf. Ada beberapa kategori mu'allaf, yaitu: (1) Orang yang baru masuk Islam, yang dilunakkan hatinya untuk betah beragama Islam, di samping pertimbangan keadaan ekonominya, dengan pemberian zakat kepadanya; (2) Orang bukan Islam yang hatinya telah dekat kepada Islam; (3) Orang bukan Islam yang bersikap memusuhi Islam. Mu'allaf yang ketiga ini, pada masa Nabi saw, diberi zakat untuk mengurangi sikap permusuhan terhadap Islam. Mu'allaf kedua diberi zakat agar cepat masuk Islam. Sedang mu'allaf pertama diberi zakat agar makin mantap dalam beragama Islam. Pemberian zakat kepada mu'allaf ketiga itu dicari illat hukumnya oleh khalifah Umar bin Khațab, dan ia mengambil ketetapan 
bahwa illat hukum memberikan zakat kepada mu'allaf ialah keadaan ia lemah agama dan keadaan umat Islam pada permulaan sejarahnya. Pada masa kekhalifahan Umar, keadaan Islam dan umatnya telah cukup kuat, dan tidak diperlukan lagi melunakkan musuh-musuh Islam, maka pemberian zakat kepada mu'allaf ketiga (yang memusuhi Islam) dihentikan, karena illat hukumnya telah tidak ada lagi. Tentu saja, pemberian zakat kepada mu'allaf yang baru saja masuk Islam, dan yang telah sangat dekat kepada Islam, tidak dihentikan (Basyir, 1988: 58).

\section{Analisis terhadap Pemikiran Umar bin Khațtab}

Tidak seorangpun dari para sahabat pada saat itu menentang terhadap pemikiran Umar bin Khațtab tentang kedudukan "al-mu'allafah qulübuhum" sebagai mustahiq zakat ini. Lain halnya dengan para ulama yang datang kemudian, mereka berbeda pendapat tentang hal itu. Terutama sekali dalam hubungannya dengan kedudukan ayat 60 surat al-Taubah tersebut. Apakah berarti ayat itu ter-mansūkh atau tidak. Juga apakah pemikiran Umar bin Khațab tentang pengguguran hak mu'allaf sebagai mustahiq zakat dapat dijadikan dasar ijtihad dalam khazanah ilmu fiqih.

Masalah utama yang menjadi persoalan di atas adalah apakah ijma' sahabat yang disimpulkan sebagai kesepakatan atas pemikiran Umar bin Khațtab dapat menasakh ketentuan Allah mengenai bagian zakat untuk golongan mu'allaf.

Di dalam teori nasakh dijelaskan bahwa tidak semua teks atau nash dapat menerima adanya nasakh. Teks atau nash bisa dinasakh manakala ketentuan baik dan buruk yang terkandung di dalamnya itu bisa berubah menurut kondisi manusia. Oleh karena itu, hukum-hukum dasar (al-ahkam al-asasiyah) yang mencakup ushuluddin, akidah, ibadah, dan nash yang mencakup fadhilah tidak bisa dinasakh karena hukum-hukum tersebut bersifat konstan atau tidak mengikuti perubahan kondisi manusia (Khallaf,1994: 355).

Di samping itu, teks atau nash hanya bisa dinasakh dengan nash lain jika sejajar kekuatannya atau lebih kuat daripadanya. Hal ini sesuai dengan kaidah : 
"Bahwasanya nash tidaklah dinasakhkan kecuali dengan nash sejajar kekuatannya atau lebih kuat daripadanya" (Khallaf, 1994: 356).

Pada dasarnya, nasakh merupakan pembatalan atas suatu hukum yang disyariatkan oleh Allah, baik itu dengan pengganti hukum lain atau tanpa pengganti sama sekali. Adapun yang berhak membatalkan hukum adalah Dia yang memiliki syariah, yaitu Allah melalui wahyu yang disampaikan kepada Nabi-Nya. Karena itu, nasakh hanya dapat terjadi pada masa hidup Rasulullah SAW., bukan sesudahnya.

Ada atau tidaknya nasakh dalam suatu hukum hanya dapat diketahui melalui dalil nash yang disampaikan oleh Syari' kepada Nabi; bahwa suatu hukum dinasakh dengan hukum lain atau suatu nash dinasakh dengan nash lain. Cara lain untuk mengetahui adanya nasakh adalah adanya dua dalil (nash) yang saling bertentangan dan tidak mungkin untuk dilakukan metode al-jam'u wa al-taufiq. Di samping itu, masa turun dari kedua nash tersebut dapat diketahui mana nash yang lebih dulu turun dan mana nash yang datang lebih akhir.

Hukum mu'allaf sebagai golongan yang berhak menerima zakat telah dipraktekkan (ma'mul bih) pada masa Nabi masih hidup. Bahkan ketika masa risalah itu sudah selesai dengan wafatnya Nabi, hukum mu'allaf masih dipraktekkan oleh Abu Bakar pada awal masa kekhalifahannya sebelum Umar bin Khatțab menghentikan pembagian zakat kepada golongan mu'allaf. Jika setelah masa risalah ketetapan hukum mu'allaf masih dipraktekkan, maka tidaklah tepat hukum mu'allaf yang secara jelas (sarih) dinashkan oleh Allah dalam Q.S. al-Taubah ayat 60 dinasakh oleh pendapatnya Umar bin Khațab.

Di dalam pendapatnya tersebut, Umar bin Khatțab secara jelas tidak mengatakan bahwa ia dengan pendapatnya hendak menasakh hukum distribusi zakat kepada golongan mu'allaf. Keengganan Umar memberikan zakat kepada golongan mu'allaf didasarkan pada alasan bahwa Islam pada saat itu sudah diberikan kemuliaan oleh Allah, yaitu kemuliaan yang belum diberikan secara sempurna ketika Nabi masih hidup. Hal ini didasarkan pada perkataan Umar bahwa pada masa Nabi, golongan mu'allaf diberikan harta zakat untuk membuat hati mereka luluh terhadap Islam. Seolah-olah menurut 
Umar, Islam pada saat itu masih dalam kondisi yang lemah karena sedikitnya pemeluk Islam. Namun ketika Islam sudah mendapatkan kemuliaan dan kejayaan dengan banyaknya pemeluk Islam, maka ia merasa sudah tidak perlu lagi untuk menta'lif mereka yang masuk dalam golongan mu'allaf. Jadi alasan ('illat) yang disampaikan oleh Umar adalah bersifat kondisional. Hal ini sesuai dengan kaidah ushuliyyah : "Tidak diingkari perubahan hukum karena perubahan zaman” (al-Zarqa, t.t: 129).

Dengan kata lain, jika pada suatu masa ada satu atau beberapa kondisi yang menuntut untuk melakukan ta'lif maka hukum tentang distribusi zakat kepada golongan mu'allaf diberlakukan kembali. Sebaliknya, jika satu atau beberapa kondisi dalam suatu masa tidak menuntut untuk melakukan ta'lif maka hukum tentang distribusi zakat kepada golongan mu'allaf ditunda pemberlakuannya.

Kemudian dalam ilmu ushul fiqh terdapat suatu kaidah hukum yang cukup populer, yaitu : "Hukum berlaku dengan ada dan tidaknya 'illat hukumnya (al-Zarqa, t.t: 300).”

Kaidah ini menegaskan bahwa hukum itu berputar bersama dengan 'illat-nya, jika ada 'illat maka ada hukum dan jika 'illat itu tiada maka hukum pun menjadi tiada. Dengan demikian, 'illat hukum adalah hal yang sangat berperan dan berpengaruh besar terhadap ada ataupun tiadanya sesuatu hukum. Suatu hukum yang bersendikan pada 'illat dapat berubah apabila 'illat itu berubah atau telah hilang. Contoh yang sangat populer yang biasa dikemukakan oleh para ulama tentang hal ini ialah mengenai hukum haramnya khamr (minuman keras yang terbuat dari perasan anggur). Keharaman khamar ini dikarenakan adanya 'illat, yaitu iskar yakni unsur memabukkan yang terdapat dalam minuman tersebut. Apabila unsur itu hilang, khamar yang semula haram itu kemudian telah menjadi cuka hukumnya menjadi halal. Jelas di sini terdapat perubahan hukum yang disebabkan perubahan 'illat hukum.

Keterangan di atas, senada dengan pemahaman mayoritas fuqaha atas pemikiran Umar bin Khațab bahwa Umar dengan pendapatnya tersebut tidak hendak menasakh ketentuan zakat bagi golongan mu'allaf, melainkan menunda sementara ketentuan tersebut karena absennya sejumlah syarat yang seharusnya terpenuhi. Dalam hal ini, sasaran zakat dikaitkan dengan 
golongan mu'allafah qulübuhum, menunjukkan bahwa ta'lif al-qulub (membujuk hati) merupakan 'illat menyerahkan zakat kepada mereka. Maka apabila 'illat itu ada - yakni pembujukan - mereka harus diberi, akan tetapi bila 'illat itu tidak ada maka mereka tidak perlu diberi. Umar merasa tidak ada kebutuhan (hajah) untuk menta'lif golongan mu'allaf pada saat itu karena Islam sudah jaya.

Kesimpulannya, bahwa kaum muslimin di masa Abu Bakar dan Umar memang benar-benar mengalami puncak kejayaannya, sehingga tidak butuh lagi untuk mencari dukungan atau merayu orang non muslim, yang hal ini berarti menafikan adanya mu'allaf. Jadi bukan menasakh ayat atau sunnah yang ada, karena hukum keduanya adalah abadi, sampai adanya kembali kebutuhan Islam akan para mu'allaf, sehingga ayat dan sunnah ini dapat kembali lagi dipraktikkan.

\section{Pandangan Ulama' terhadap Pemikiran Umar bin Khațab}

Rasulullah biasanya memberikan bagian ini pada kepala suku Arab tertentu dengan tujuan untuk menarik mereka agar memeluk Islam atau mencegah mereka agar tidak membahayakan kaum muslimin. Bagian ini diberikan pula pada orang-orang muslim yang baru sehingga mereka dapat tetap memeluk Islam dengan teguh. Tetapi Umar mencabut perintah yang dituliskan Abu Bakar dikala ia masih menjadi khalifah untuk memberikan tanah-tanah tertentu pada sejumlah orang. Atas dasar ini, Umar berpendapat bahwa Rasulullah telah memberikan bagian itu untuk memperkuat Islam, tetapi karena keadaan telah berubah maka bagian itu tidak berlaku lagi. Tindakan Umar ini tampaknya bertolak belakang dengan al-Qur'an, tetapi sebenarnya ia mempertimbangkan situasi yang ada dan mengikuti ruh perintah al-Qur'an. Pertimbangan pribadinya membawanya pada keputusan bahwa seandainya Rasulullah hidup dalam kondisi yang sama, tentu beliau akan memutuskan hal yang serupa (Hasan, 1970: 107).

Mengenai pendapat yang mengatakan bahwa bagian mu'allaf pernah digugurkan terdapat pula dua tinjauan yang berbeda yang dampaknya ikut mempengaruhi perkembangan pemikiran dewasa ini. Tinjauan pertama mengatakan bahwa konsensus (persetujuan umum) sahabat yang terjadi pada 
masa Abu Bakar yang menggugurkan bagian mu'allaf tersebut telah menasakh bagian mu'allaf yang terdapat pada ayat 60 surat al-Taubah. Pemikiran semacam inilah barangkali yang membawa adanya teori lokal dan temporal pada ayat-ayat al-Qur'an. Sementara itu tinjauan yang kedua berpendapat bahwa pengguguran bagian mu'allaf pada masa sahabat itu bukanlah berarti sama dengan pembatalan (nasakh), tetapi yang sebenarnya adalah 'penghentian hukum disebabkan berhenti (tidak terpenuhi) 'illat-nya.' Pendekatan yang kedua ini nampaknya membuka pintu bagi teori adanya sifat-sifat situasional dan kondisional ayat-ayat al-Qur'an (Nuruddin, 1987: $143)$.

Ibnu Rusyd (526-595 H) dalam memberikan jawaban terhadap pertanyaan, "masih adakah orang-orang mu'allaf pasca periode awal Islam?" mengatakan, "Imam Malik berkata, sekarang sudah tidak ada lagi mu'allaf. Imam Al-Shafi'i dan Abu Hanifah mengatakan, bahwa bagian atau hak mu'allaf untuk mendapatkan zakat adalah abadi sepanjang masa, jika memang imam berpendapat demikian. Mereka adalah orang-orang yang dibujuk hatinya olah imam (penguasa) demi kepentingan Islam. Adapun sebab perbedaan pendapat mereka dalam masalah ini adalah, apakah kekhususan ini hanya untuk Nabi ataukah juga untuk umatnya secara umum? Tentu, jawabannya adalah untuk umum. Apakah kebolehan bagi imam untuk memberikan bagian itu mutlak atau terbatas? Artinya, apakah hanya dalam kondisi-kondisi lemah saja, seorang imam boleh memberikan hak itu?

Berdasar inilah, Imam Malik mengatakan, "Sekarang kita tidak butuh lagi mu'allaf. Karena Islam sudah sangat kuat. Inilah sebagaimana diketahui dari sudut pandang berdasar kemaslahatan (Ibnu Rusyd, tt., 613).

Dengan demikian, pada dasarnya tidak ada perbedaan signifikan antara ketiga Imam madzhab tersebut, Malik, Al-Shafi'i, dan Abu Hanifah. Karena pandangan Imam Malik berdasar pada kondisi umat Islam saat itu, yang memang dianggapnya benar-benar kuat, sehingga illat (alasan) untuk memberi mereka bagian zakat hilang. Adapun jika demi kemaslahatan muslimin adalah dengan memberi bagian kepada mereka. Maka illat itu muncul lagi, sehingga mereka kembali diberikan haknya. Dan parameter maslahat ini dikembalikan sepenuhnya kepada imam, yang hal ini adalah sesuai dengan pendapat Imam Al-Shafi'i dan Abu Hanifah. 
Sayyid Sābiq (1915-2000 M) berpendapat, bahwa apa yang dilakukan Umar merupakan hasil ijtihadnya sendiri. Umar melihat bahwa memeberikan pemberian kepada mereka (mu'allaf) setelah Islam tumbuh dengan kokoh di dalam bangsa Arab tidak mengandung maslahat. Jika mereka keluar dari Islam, hal itu tidak menimbulkan dampak yang merugikan terhadap Islam. Adapun Uthman dan Ali yang tidak memberikan bagian zakat kepada mu'allaf tidak dapat dijadikan alasan terhapusnya bagian mu'allaf karena bisa jadi keduanya pada saat itu memandang tidak perlu memberikan zakat kepada orang kafir. Hal ini tidak bertentangan dengan tetapnya bagian mu'allaf untuk orang yang membutuhkan. Terlepas dari itu semua landasan utama dalam istidlal adalah Al-Qur'an dan as-Sunnah. Kedua sumber inilah yang harus dijadikan pegangan.

Pendapat yang kuat adalah yang mengatakan bahwa memberikan bagian mu'allaf kepada orang kafir ketika dipandang perlu adalah boleh. Jika pada suatu saat ada kaum kafir yang tidak mau menaati pemerintah, kecuali karena dunia dan pemerintah tidak mempu membuat mereka masuk Islam kecuali dengan paksaan, maka pemerintah boleh memberikan zakat kepada mereka. Tersebarnya Islam dalam keadaan itu tidak dapat menjadi alasan untuk menggugurkan bagian mu'allaf (Sābiq, 2009: 680).

Yusuf Qarḍāwi (1926-1961 M) berpendapat bahwa pengakuan adanya nasakh dengan perbuatan Umar sama sekali tidak bisa dijadikan alasan. Umar hanya mengharamkan memberi zakat kepada sekelompok orang yang pernah mendapatkan bagian mu'allaf di zaman Rasulullah. Ia berpendapat, bahwa sekarang sudah tidak diperlukan lagi membujuk hati mereka, karena Allah telah memperkuat Islam. Umarlah yang benar dengan tidak berlebihan atas perbuatannya itu, karena mu'allaf itu bukan sesuatu yang bersifat tetap dan tidak pula seorang yang mu'allaf pada suatu masa, tetap mu'allaf pula pada masa yang lain. Dan penetapan ada tidaknya kebutuhan pada mu'allaf serta penentuan orang-orangnya, adalah masalah yang harus dikembalikan kepada penguasa. Merekalah yang menentukan apa yang lebih baik dan bermanfaat bagi Islam dan kaum Muslimin (Qarḍāwi, 2002: 571).

Umar bin Khațab ketika menghilangkan golongan mu'allaf itu tidak berarti menentang nash atau menasakh syara'. Karena zakat itu harus diberikan kepada kelompok aṣnāf yang delapan, yang telah dijadikan Allah 
sebagai orang yang berhak mendapatkan.

Apabila salah satu aṣnāf tidak ada, maka hilanglah bagiannya. Bila terjadi demikian, jangan dikatakan bahwa hal itu bertentangan dengan kitab Allah atau merupakan nasakh padanya. Misalnya, apabila tidak ada bagian "riqāb/untuk memerdekakan budak belian", seperti di zaman kita sekarang yang menghilangkan perbudakan perorangan, maka hilanglah bagian ini. Tetapi jangan dinyatakan, bahwa dengan hilangnya bagian ini telah menasakh Al-Qur' an atau bertentangan dengan nash (Qarḍāwi, 2002: 571).

Dengan demikian apa yang diperbuat Umar dengan alasan apa pun juga bukan merupakan nasakh atau penghapusan terhadap hukum memberi zakat pada golongan mu'allaf, apalagi bila hal itu dinyatakan sebagai ijma' sahabat. Demikian pula pendapat yang menyatakan bahwa sekarang tidak ada mu'allaf, sama sekali bukan nasakh, akan tetapi hal itu hanya pemberitahuan dari suatu keadaan di masanya.

Dari uraian pendapat-pendapat ulama di atas, dapat diambil garis besar bahwa ulama-ulama khalaf di sini sepakat bahwa bagian golongan mu'allaf ini tetap ada, tidak pernah dinasakh, telah ditetapkan dengan nash yang sudah pasti, yaitu ayat Al-Qur'an yang terdapat dalam surat al-Taubah, yang termasuk kelompok terakhir ayat Al-Qur'an yang diturunkan.

Para ulama seperti Sayyid Sābiq, Yusuf Qarḍāwi dan Hasbi ashShiddieqy mendudukkan dengan tepat terhadap pemikiran Umar bin Khațab yang berkenaan dengan pengguguran hak mu'allaf sebagai mustahiq zakat (Ash-Shidieqy, 1971). Mereka mengatakan bahwa Abu Bakar sama sekali tidak menolak ucapan dan perbuatan Umar itu, demikian pula para sahabat, sehingga masalah tersebut merupakan kesepakatan (ijma') para sahabat.

\section{Penutup}

Dari deskripsi di atas dapat diambil kesimpulan tentang pemikiran Umar bin Khațab, yaitu bahwa alasan ijtihad Umar bin Khaṭtab menggugurkan hak bagi aṣnāf "al-mu'allafah qulūbuhum" sebagai penerima zakat adalah karena adanya suatu 'illat (alasan-alasan di balik solusi-solusi dan keputusan tersebut) yaitu keadaan "lemah agama" dan keadaan umat Islam pada permulaan sejarahnya yang masih minoritas sehingga kelompok 
"al-mu'allafah qulūbuhum" diberi bagian harta zakat. Hal itu di samping mereka diharapkan berubah dan masuk Islam, juga untuk menolak kemungkinan datangnya kejahatan dari mereka. Namun pada masa khalifah Abu bakar, keadaan umat Islam telah cukup kuat dan tidak diperlukan lagi untuk melunakkan musuh-musuh Islam, maka pemberian zakat kepada golongan mu'allaf (dari golongan orang kafir) dihentikan Umar bin Khațtab, karena 'illat hukumnya sudah tidak ada lagi.

Adapun pendapat para ulama terhadap hasil pemikiran Umar bin Khațtab yang tidak memberikan hak memperoleh zakat bagi aṣnāf "almu'allafah qulūbuhum" dari golongan orang kafir, tidak seorang pun sahabat menentangnya pada saat itu (pada masa khalifah Abu Bakar dan pada masa khalifah Umar bin Khatțab itu sendiri). Akan tetapi lain halnya dengan ulama yang datang kemudian, mereka berbeda pendapat mengenai status aṣnăf "al-mu'allafah qulübuhum". Namun demikian, pada umumnya mereka tidak menyalahi apa yang telah dilakukan Umar pada saat itu. Ulama-ulama khalaf (kontemporer) di sini sepakat bahwa bagian golongan mu'allaf ini tetap ada, tidak pernah dinasakh, telah ditetapkan dengan nash yang sudah pasti, yaitu ayat Al-Qur'an yang terdapat dalam surat al-Taubah, yang termasuk kelompok terakhir ayat Al-Qur'an yang diturunkan. Para ulama seperti Sayyid Sābiq, Yusuf Qarḍāwi, Hasbi ash-Shiddieqy, dan yang lainnya mendudukkan pemikiran Umar bin Khațab berkenaan tentang pengguguran hak mu'allaf sebagai mustahiq zakat, secara tepat. Mereka menyebutkan, bahwa Abu Bakar sama sekali tidak menolak ucapan dan perbuatan Umar itu, demikian pula para sahabat, sehingga masalah tersebut merupakan kesepakatan (ijma') para sahabat.

\section{Daftar Pustaka}

Al-Aqqad, Abbas Mahmud, t.t. Abqariyyatu Umar. Dār al-Hilāl.

Al-Bukhari, Abi Abdillah Muhammad bin Ismail, t.t. Șaḥīh al-Bukhāri, Juz II, Dār ibni Kathīr.

Al-Harithi, Jaribah bin Ahmad. 2006. Fikih Ekonomi Umar bin Al-Khattab, Jakarta: Khalifa.

Al-Naisabūri, Imam Abu al-Husain Muslim bin al-Ḥajjāj al-Qusyairi. t.t. Ṣaḥihh Muslim, Juz IV, Beirut: Dār Iḥyā’ al-Turāth al-‘Arabi. 
Al-Suyuṭi. 2010. Tārikh al-Khulafā', Jakarta: Pustaka Al-Kauthar.

Al-Shaukani. t.t. Nail al-Auțār, jil. III, Beirut: Dār al-Kutub al-'Ilmiyah.

Al-Taaāri. t.t. Tafsīr al-Tabāri, jilid. 6, Beirut: Dār al- Kutub al-Ilmiyah.

Al-Tirmidhi. t.t. Sunan al-Tirmidhi, Juz V, Dar Ihya' al-Turath Al-Arabi.

Ash-Shidieqy, Teungku Muhammad Hasbi. 1971. Sejarah pertumbuhan dan Perkembangan Hukum Islam, Jakarta: Bulan Bintang.

Baltaji, Muhammad. 2005. Metodologi Ijtihad Umar bin al-Khattab, Jakarta: Khalifa,

Basyir, Ahmad Azhar. t.t. Pokok-pokok Ijtihad dalam hukum Islam, dalam Jalaludin Rohmad, 1988. Ijtihad dalam Sorotan, Bandung: Mizan.

Haekal, Muhammad Husain. 2011. Umar bin Khațtab. Bogor : Litera AntarNusa.

Hasan, Ahmad. 1970. Pintu Ijtihad Sebelum Tertutup, terj. The early development of Islamic Jurisprudence, Bandung : Pustaka.

Kathir, Ibnu, t.t.Tartīb wa Tahdhīb Kitāb al-Bidāyah wa al-Nihāyah, (terj. Al-Bidayah Wa al-Nihayah Masa Khulafa'ur Rasyidin), Jakarta: Dār al-Haq.

Khallāf, Abdul Wahhāb. 1994. Ilmu Ushul Fiqh, (edisi terj.). Semarang: Dina Utama.

Nuruddin, Amiur. 1987. Ijtihad 'Umar ibn al-Khaththab: Studi tentang Perubahan Hukum dalam Islam, Jakarta: Rajawali Pers.

Qarḍ̄awi, Yusuf. 2002. Hukum Zakat. Bogor: Pustaka Litera Antar Nusa.

Qayyim, Ibnul, A’lām Al-Muwaqqi'īn, juz. I, Beirut: Dār al-Kutub al'Ilmiyyah.

Rusyd, Ibnu. Bidāyatu al-Mujtahid Analisa Fiqih Para Mujtahid, terj. jil. I. Jakarta: Pustaka Amani.

Sābiq, Sayyid. 1983. Fiqh al-Sunnah. Vol. 1. Beirut: Dār al-Fikr.

Syalabi, A. 1998. Sejarah dan Kebudayaan Islam, Jakarta: Pustaka Al-Husna.

Zahrah, Muhammad Abu, Tārīkh al-Madhāhib al-Islāmiyyah, Mesir: Dār alfikr al-'Arabi. 